\title{
BCL-6: a possible missing link for anti-inflammatory PPAR- $\delta$ signalling in pancreatic beta cells
}

\author{
I. Kharroubi • C.-H. Lee • P. Hekerman • M. I. Darville • \\ R. M. Evans • D. L. Eizirik • M. Cnop
}

Received: 5 April 2006 /Accepted: 15 May 2006 / Published online: 5 August 2006

(C) Springer-Verlag 2006

\begin{abstract}
Aims/hypothesis Inflammatory mediators contribute to pancreatic beta cell death in type 1 diabetes. Beta cells respond to cytokine exposure by activating gene networks that alter cellular metabolism, induce chemokine release (thereby increasing insulitis), and cause apoptosis. We have previously shown by microarray analysis that exposure of INS$1 \mathrm{E}$ cells to IL- $1 \beta+$ IFN- $\gamma$ induces the transcription factor peroxisome proliferator-activated receptor (Ppar)- $\delta$ and several of its target genes. PPAR- $\delta$ controls cellular lipid metabolism and is a major regulator of inflammatory responses. We therefore examined the role of PPAR- $\delta$ in cytokine-treated beta cells.

Materials and methods Primary beta cells that had been purified by fluorescence-activated cell sorting and INS-1E
\end{abstract}

Electronic supplementary material Supplementary material is available for this article at http://dx.doi.org/10.1007/s00125-006$0366-5$ and is accessible to all authorized users.

I. Kharroubi · P. Hekerman • M. I. Darville · D. L. Eizirik •

M. Cnop $(\bowtie)$

Laboratory of Experimental Medicine,

Université Libre de Bruxelles,

CP-618, 808 Route de Lennik,

Brussels 1070, Belgium

e-mail: monop@ulb.ac.be

C.-H. Lee

Department of Genetics and Complex Diseases,

Harvard School of Public Health,

Boston, MA, USA

R. M. Evans

The Salk Institute for Biological Studies,

La Jolla, CA, USA

M. Cnop

Division of Endocrinology, Erasmus Hospital,

Brussels, Belgium cells were cultured in the presence of the cytokines TNF- $\alpha$, IL- $1 \beta$, or IL- $1 \beta+$ IFN- $\gamma$, or the synthetic PPAR- $\delta$ agonist GW501516. Gene expression was analysed by real-time PCR. PPAR- $\delta$, monocyte chemoattractant protein (MCP-1, now known as CCL2) promoter and NF-KB activity were determined by luciferase reporter assays.

Results Exposure of primary beta cells or INS-1E cells to cytokines induced Ppar- $\delta$ mRNA expression and PPAR- $\delta$ dependent $C D 36$, lipoprotein lipase, acyl CoA synthetase and adipophilin mRNAs. Cytokines and the PPAR- $\delta$ agonist GW501516 also activated a PPAR- $\delta$ response element reporter in beta cells. Unlike immune cells, neither INS-1E nor beta cells expressed the transcriptional repressor B-cell lymphoma-6 (BCL-6). As a consequence, PPAR- $\delta$ activation by GW501516 did not decrease cytokine-induced $M c p-1$ promoter activation or mRNA expression, as reported for macrophages. Transient transfection with a BCL-6 expression vector markedly reduced $M c p-1$ promoter and NF- $\mathrm{KB}$ activities in beta cells.

Conclusions/interpretation Cytokines activate the PPAR- $\delta$ gene network in beta cells. This network does not, however, regulate the pro-inflammatory response to cytokines because beta cells lack constitutive BCL-6 expression. This may render beta cells particularly susceptible to propagating inflammation in type 1 diabetes.

Keywords Apoptosis · BCL-6 · Cytokine - Islet · MCP-1 . $\mathrm{NF}-\mathrm{kB} \cdot$ Pancreatic beta cell $\cdot$ PPAR- $\delta \cdot$ Type 1 diabetes mellitus

\begin{tabular}{|c|c|}
\hline \multicolumn{2}{|c|}{ Abbreviations } \\
\hline ADRP & adipocyte differentiation-related protein \\
\hline AoX & acyl CoA oxidase \\
\hline BCL-6 & B-cell lymphoma-6 \\
\hline CD36 & scavenger receptor B \\
\hline
\end{tabular}


FACS fluorescence-activated cell sorting

FBS fetal bovine serum

GAPDH glyceraldehyde-3-phosphate dehydrogenase

I $\mathrm{B}-\alpha$ inhibitor $\kappa \mathrm{B}-\alpha$

iNOS inducible nitric oxide synthase

LPL lipoprotein lipase

MCP monocyte chemoattractant protein

$\mathrm{NF}-\kappa \mathrm{B}$ nuclear factor $\kappa \mathrm{B}$

PPAR peroxisome proliferator-activated receptor

PPRE peroxisome proliferator response element

\section{Introduction}

Type 1 diabetes results from an autoimmune destruction of pancreatic beta cells, caused by a complex interplay between beta cells and the immune system. During the early stages of insulitis, activated macrophages and $\mathrm{T}$ lymphocytes are attracted to the islets of Langerhans. These cells release oxygen free radicals, nitric oxide and cytokines such as IL- $1 \beta$, IFN- $\gamma$ and TNF- $\alpha$ in the vicinity of the islet cells, contributing to beta cell dysfunction and apoptosis [1].

Cytokine-induced beta cell apoptosis depends on de novo gene expression [1]. To determine the nature of the genes implicated in this process, we previously performed a series of microarray studies in cytokine-treated beta cells (reviewed in [2]). We observed that nuclear factor- $\mathrm{kB}$ $(\mathrm{NF}-\mathrm{kB})$ is a key regulatory transcription factor with a proapoptotic role in beta cells [3-5]. NF- $\mathrm{kB}$ also contributes to the induction of the cytokine IL-15 and the chemokines monocyte chemoattractant protein-1 (MCP-1, now known as CCL2), interferon-inducible protein-10 and intercellular adhesion molecule- 1 in the beta cell [3]. These chemokines contribute to the recruitment and activation of mononuclear cells and to the development of insulitis in early type 1 diabetes and during islet graft destruction [6]. The microarray analyses of IL- $1 \beta$ plus IFN- $\gamma$-exposed beta cells also revealed changes in the expression of numerous genes involved in lipid metabolism, among them the transcription factor peroxisome proliferator-activated receptor (Ppar)- $\delta$ and its target genes scavenger receptor B (CD36), lipoprotein lipase $(L p l)$, acyl CoA synthetase and adipocyte differentiation-related protein (Adrp, also known as adipophilin or Adfp) [7].

PPAR- $\delta$ (also called PPAR- $\beta$ ) belongs to the PPAR nuclear receptor family, which regulates transcription by binding to peroxisome proliferator response elements (PPREs). PPAR- $\alpha$ and PPAR- $\gamma$ control cellular lipid metabolism, and PPAR- $\gamma$ also affects the activity of the proinflammatory transcription factors STAT and NF- $\mathrm{KB}$ in macrophages [8]. The role of PPAR- $\delta$ is less well understood. In keeping with its ubiquitous expression,
PPAR- $\delta$ has been implicated in placentation, cellular proliferation and differentiation, lipid metabolism and inflammation [9]. Synthetic PPAR- $\delta$ agonists promote cholesterol uptake [10] and efflux [11] in macrophages via regulation of $\mathrm{CD} 36$ and the ATP-binding cassette A1. In muscle, PPAR- $\delta$ overexpression or its activation by synthetic ligands induces lipid utilisation [12-14], while in the liver PPAR- $\delta$ promotes the synthesis of NEFA [15].

In addition to these effects on lipid metabolism, it was recently shown that PPAR- $\delta$ has a role in inflammation in atherogenesis [16]. Thus, deletion of PPAR- $\delta$ in foam cells was atheroprotective through the increased availability of inflammatory repressors and the downregulation of the pro-inflammatory genes $M c p-1, I L-1 \beta$ and matrix metalloproteinase 9. While unliganded PPAR- $\delta$ sequesters the transcriptional repressor protein B cell lymphoma-6 (BCL-6) and has mainly proinflammatory effects, following ligand binding BCL-6 is released from PPAR- $\delta$ and inhibits inflammatory signals. Hence, deletion of PPAR- $\delta$ exerts anti-inflammatory effects, as does PPAR- $\delta$ activation by synthetic ligands [16]. PPAR- $\delta$ was therefore suggested to control an inflammatory switch through its ligand-dependent association with and dissociation from the transcriptional repressor BCL-6 [16].

PPAR $-\delta$ is the predominant PPAR isoform in islets [17], but little is known about its role in beta cells. Based on our previous observations that cytokines induce both Ppar- $\delta$ and the expression of proinflammatory chemokines in beta cells [7], we sought to determine whether the PPAR- $\delta$ network is present and active in beta cells and whether PPAR- $\delta$ activation modulates the inflammatory response of beta cells exposed to cytokines via its association with the transcriptional repressor BCL-6.

\section{Materials and methods}

Culture of primary beta cells purified by fluorescenceactivated cell sorting and of insulin-producing INS-1E cells

Male Wistar rats (Charles River Laboratories Belgium, Brussels, Belgium) were housed and utilised in accordance with the guidelines of the Belgian Regulations for Animal Care and the Principles of Laboratory Animal Care (NIH publication no. 85-23, revised 1985; http:/grants1.nih.gov/ grants/olaw/references/phspol.htm accessed on 4 April 2005). Rat islets were isolated by collagenase digestion followed by hand picking under a stereomicroscope. For beta cell isolation, islets were dispersed and beta cells were purified by autofluorescence-activated cell sorting (FACS, FACStar, Becton-Dickinson and Co, Sunnyvale, CA, USA) ([18] and references therein). The preparations used in the present experiments contained $93 \pm 1 \%$ beta cells. Purified 
beta cells were pre-cultured for $16 \mathrm{~h}$ in HAM's F-10 medium containing $10 \mathrm{mmol} / \mathrm{l}$ glucose, $2 \mathrm{mmol} / \mathrm{l}$ glutamine, $50 \mu \mathrm{mol} / 1$ 3-isobutyl-1-methylxanthine, 5\% heat-inactivated fetal bovine serum (FBS), $0.5 \%$ BSA, $50 \mathrm{U} / \mathrm{ml}$ penicillin and $50 \mu \mathrm{g} / \mathrm{ml}$ streptomycin and then changed to serum-free medium with $1 \%$ BSA [18]. The well-differentiated INS-1E beta cell line, a kind gift from C. Wollheim (Centre Medical Universitaire, Geneva, Switzerland), was cultured in RPMI-1640 (with Glutamax-1) supplemented with $10 \mathrm{mmol} / 1 \mathrm{HEPES}, 5 \% \mathrm{FBS}, 100 \mathrm{U} / \mathrm{ml}$ penicillin, $100 \mu \mathrm{g} / \mathrm{ml}$ streptomycin, $1 \mathrm{mmol} / \mathrm{l}$ sodium pyruvate and $50 \mu \mathrm{mol} / 1$ 2-mercaptoethanol [19]. FACS-purified beta cells and INS-1E cells were exposed to the cytokines IL-1 $\beta$ $(50 \mathrm{U} / \mathrm{ml}$ for beta cells, $10 \mathrm{U} / \mathrm{ml}$ for INS-1E cells; kindly provided by C. W. Reynolds, National Cancer Institute, Bethesda, MD, USA), IFN- $\gamma(500 \mathrm{U} / \mathrm{ml}, \mathrm{R} \& \mathrm{D}$ Systems, Oxon, UK) and TNF- $\alpha$ (1000 U/ml, Innogenetics, Gent, Belgium). Cytokine concentrations were selected based on our previous time course and dose-response studies [1, 7].

Determination of mRNA expression

Poly(A) ${ }^{+}$RNA was isolated from purified beta cells and INS-1E cells using oligo(dT)25-coated polystyrene Dynabeads (Dynal, Oslo, Norway), and reverse transcribed as previously described [20]. Standards for each gene were amplified by PCR using appropriate primers. Real-time PCR products were quantified using SYBR Green [21], and their concentration was calculated as copies/ $\mu$ l by comparison with the standard curve [22]. The mRNAs analysed were: Ppar- $\delta, A d r p, C D 36$, acyl CoA synthetase, inducible nitric oxide synthase (iNOS), Mcp-1 and the inhibitor $\mathrm{kB}-\alpha$ $(I \kappa B-\alpha)$. The expression levels of the genes of interest were corrected for that of the house-keeping gene glyceraldehyde-3-phosphate dehydrogenase (Gapdh) $[21,22]$. The specific real-time PCR primers and their respective PCR product lengths are available as electronic supplementary material (ESM). For $B c l-6$, a conventional PCR was performed as described [23] using forward primer 5'-CTGAGGGAAGGCAACATCAT-3' and reverse primer 5'-CGGCTGTTCAGGAACTCTTC-3' yielding a PCR product of $975 \mathrm{bp}$. The ethidium bromide-stained agarose gels were photographed under UV transillumination using a Kodak Digital Science DC 290 camera (Kodak, Rochester, NY, USA).

\section{Luciferase reporter assays}

To determine whether PPAR- $\delta$ is functional in beta cells, primary beta and INS-1E cells were transfected with a PPAR- $\delta$ reporter construct containing three copies of the acyl CoA oxidase (AoX) PPRE cloned upstream of the gene encoding the thymidine kinase luciferase reporter
[24]. In parallel, cells were transfected with the parental plasmid (without PPRE). To evaluate the effect of PPAR- $\delta$ activation on cytokine-induced MCP-1 and NF- $\mathrm{KB}$ activation, we used, respectively, the pMCP-1-514(enh) luc construct containing two NF- $\mathrm{KB}$ binding sites [25] and the NF- $\mathrm{kB}$ reporter construct (BD biosciences Clontech, Palo Alto, CA, USA). In all conditions, cells were co-transfected with the internal control plasmid pRL-CMV (Promega, Madison, WI USA). Transfections were performed by 5 h lipofection with lipofectAMINE 2000 (Invitrogen, Paisley, UK), as previously described [26], using $0.5 \mu \mathrm{l}$ lipofectamine, $135 \mathrm{ng}$ test plasmid and $15 \mathrm{ng}$ pRL-CMV for primary beta cells, and 250 and $25 \mathrm{ng}$ of the respective plasmids for INS-1E cells. The cells were subsequently exposed for 6-24 h to GW501516 or cytokines. In a second series of experiments, $250 \mathrm{ng}$ haemagglutinin-tagged BCL6 expression or control plasmids (a kind gift from A. L. Dent, Indiana University School of Medicine, IN, USA) were co-transfected with the $M c p-1$ promoter or NF-KB reporter and $\mathrm{pRL}-\mathrm{CMV}$ plasmids. Luciferase activities were assayed with the Dual-Luciferase Reporter Assay System (Promega). Test values were corrected for the luciferase activity value of the internal control pRL-CMV. The different conditions tested did not affect pRL-CMV activity.

Rat islet insulin secretion

Rat islets were exposed to GW501516 $(1 \mu \mathrm{mol} / \mathrm{l})$ for $24 \mathrm{~h}$, after which their acute glucose-induced and palmitateinduced insulin release was measured as previously described [27]. Briefly, triplicate groups of ten islets were incubated for $90 \mathrm{~min}$ in Krebs-Ringer bicarbonate buffer supplemented with $0.5 \%$ BSA and the secretagogues indicated in Table 1. Insulin release was corrected per islet insulin content and expressed as fold-increase compared to basal insulin release at $1.7 \mathrm{mmol} / \mathrm{l}$ glucose.

Table 1 Rat islet insulin secretion

\begin{tabular}{lll}
\hline Stimulus & Control & GW501516 \\
\hline $1.7 \mathrm{mmol} / 1$ glucose & $1.0 \pm 0.0$ & $1.0 \pm 0.0$ \\
$5.6 \mathrm{mmol} / 1$ glucose & $2.4 \pm 0.6$ & $1.8 \pm 0.1^{*}$ \\
$16.7 \mathrm{mmol} / 1$ glucose & $4.0 \pm 0.9^{*}$ & $4.3 \pm 0.8^{*}$ \\
$16.7 \mathrm{mmol} / 1$ glucose + & $6.9 \pm 0.8^{*}$ & $8.4 \pm 0.7^{*}$ \\
$0.5 \mathrm{mmol} / 1$ palmitate & & \\
\hline
\end{tabular}

Data are expressed as fold-increase compared to insulin secretion at $1.7 \mathrm{mmol} / 1$ glucose and represent mean $\pm \mathrm{SE}$ of four independent experiments

$* p<0.05$ for comparison against $1.7 \mathrm{mmol} / 1$ glucose. There was no difference between control and GW501516-treated islets 
Determination of cell viability

To determine the effect of GW501516 on cytokine-induced beta cell apoptosis, the percentage of viable, apoptotic and necrotic cells was determined after $48 \mathrm{~h}$ of cytokine exposure. The treatment with GW501516 was initiated $12 \mathrm{~h}$ before the addition of IL- $1 \beta(50 \mathrm{U} / \mathrm{ml})$ and IFN- $\gamma$ $(500 \mathrm{U} / \mathrm{ml})$. To assess cell viability, FACS-purified beta cells were incubated for $15 \mathrm{~min}$ with the DNA-binding dyes propidium iodide $(10 \mu \mathrm{g} / \mathrm{ml}$; Sigma, Bornem, Belgium) and Hoechst 33342 (10 $\mu \mathrm{g} / \mathrm{ml}$; Sigma) [5, 7, 28]. In each experimental condition a minimum of 500 cells was counted by at least two observers, one of them blinded for the sample identity. There was $>90 \%$ agreement between observers in the different assessments of viability, confirming the reproducibility of the method.

\section{Statistical analysis}

Data are presented as means $\pm \mathrm{SE}$. Comparisons were performed by two-sided paired Student's $t$-test or ANOVA followed by paired $t$-test with the Bonferroni correction for multiple comparisons. A $p$-value $<0.05$ was considered statistically significant.

\section{Results}

Cytokines induce Ppar- $\delta$ mRNA expression in pancreatic beta cells

INS-1E cell exposure to TNF- $\alpha$ or IL- $1 \beta$, alone or in combination with IFN- $\gamma$, increased Ppar- $\delta$ expression (Fig. 1a). The induction occurred early (at $6 \mathrm{~h}$ ) and was most pronounced (fivefold increase) for the combination of IL-1 $\beta$ and IFN- $\gamma$. Ppar- $\delta$ expression was also induced in FACS-purified primary rat beta cells exposed to IL-1 $\beta$ and IFN- $\gamma$ for $6 \mathrm{~h}$ (2.2-fold, Fig. 1b), while mRNA levels returned to control levels after $24 \mathrm{~h}$ in both cell types. These data are in good agreement with our previous microarray analysis observations [7].

Cytokines induce PPAR- $\delta$ target gene expression in beta cells

CD36 mRNA expression increased twofold in INS-1E and primary beta cells treated for 6 or $24 \mathrm{~h}$ with IL-1 $\beta$ alone or in combination with IFN- $\gamma$ (Fig. 2a,b). INS-1E $\mathrm{Lpl}$ expression levels increased three- to sixfold following exposure to IL- $1 \beta$ or IL- $1 \beta+$ IFN- $\gamma$ (Fig. $2 c, d$ ). In beta cells, $L p l$ induction was observed with IL-1 $\beta$ but not with IL- $1 \beta+$ IFN- $\gamma$. IL- $1 \beta$ and/or IFN- $\gamma$ also increased acyl CoA synthetase mRNA levels at 6 and $24 \mathrm{~h}$ by two- to sixfold in INS-1E cells, and by 1.5 - to twofold in primary beta cells (Fig. 2e,f). Finally, we observed increased Adrp mRNA expression in INS-1E cells exposed to TNF- $\alpha$ or IL- $1 \beta+$ IFN- $\gamma$, and in primary beta cells treated with IL$1 \beta$ alone or in combination with IFN- $\gamma$ (Fig. $2 \mathrm{~g}, \mathrm{~h}$ ). There was some variability in the timing and magnitude of PPAR$\delta$ target gene induction in INS-1E and primary beta cells but as a whole these data suggest that the Ppar- $\delta$ mRNA induction at $6 \mathrm{~h}$ is followed by upregulation of downstream PPAR- $\delta$ target genes at 6 and $24 \mathrm{~h}$.

Cytokines activate the PPAR- $\delta$ nuclear receptor in beta cells

Following transfection with the $A o X$-PPRE luciferase reporter, primary beta cells were exposed for $12-24 \mathrm{~h}$ to IL- $\beta+$ IFN- $\gamma$ or to the synthetic PPAR- $\delta$ agonist GW501516 (0.1-1 $\mu \mathrm{mol} / \mathrm{l})$, used as a positive control. Cytokines activated PPAR- $\delta$, as indicated by the fourfold increase in luciferase activity after $12 \mathrm{~h}$, which fell to about twofold after $24 \mathrm{~h}$ (Fig. 3a,b). GW501516 treatment led to a twofold increase in luciferase activity after 12 and $24 \mathrm{~h}$ at a concentration of $1 \mu \mathrm{mol} / 1$ (Fig. 3). This concentration of
Fig. 1 Cytokines induce Ppar- $\delta$ expression in beta cells. INS-1E (a) or FACS-purified primary beta cells (b) were cultured for 6-24 h under control conditions (empty bars), or with TNF- $\alpha$ (dotted bars), IL-1 $\beta$ (grey bars) or IL-1 $\beta+$ IFN- $\gamma$ (black bars). Ppar- $\delta$ mRNA expression was analysed by real-time PCR and the data were normalised for the expression of the housekeeping gene Gapdh. Data represent means \pm SE of three to eight independent experiments. ${ }^{*} p<0.05$, ${ }^{* *} p<0.01, * * * p<0.001$ vs control
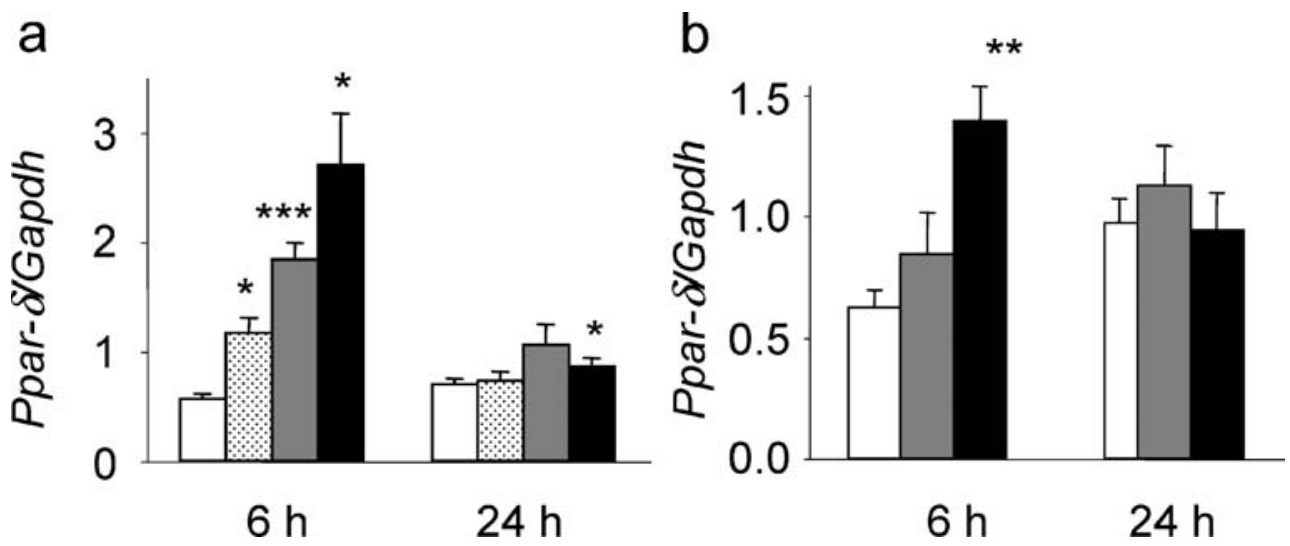
Fig. 2 Cytokines induce

PPAR- $\delta$ target gene expression in beta cells. INS-1E $(\mathbf{a}, \mathbf{c}, \mathbf{e}, \mathbf{g})$ or FACS-purified primary beta cells $(\mathbf{b}, \mathbf{d}, \mathbf{f}, \mathbf{h})$ were cultured for 6-24 h under control conditions (empty bars), or with TNF- $\alpha$ (dotted bars), IL-1 $\beta$ (grey bars) or IL-1 $\beta+\mathrm{IFN}-\gamma$ (black bars). CD36, Lpl, acyl CoA synthetase and Adrp mRNA expression was analysed by real-time PCR and the data were normalised for the expression of the housekeeping gene Gapdh. Data represent means \pm $\mathrm{SE}$ of three to eight independent experiments. ${ }^{*} p<0.05$, $* * p<0.01,{ }^{* * *} p<0.001$ vs control
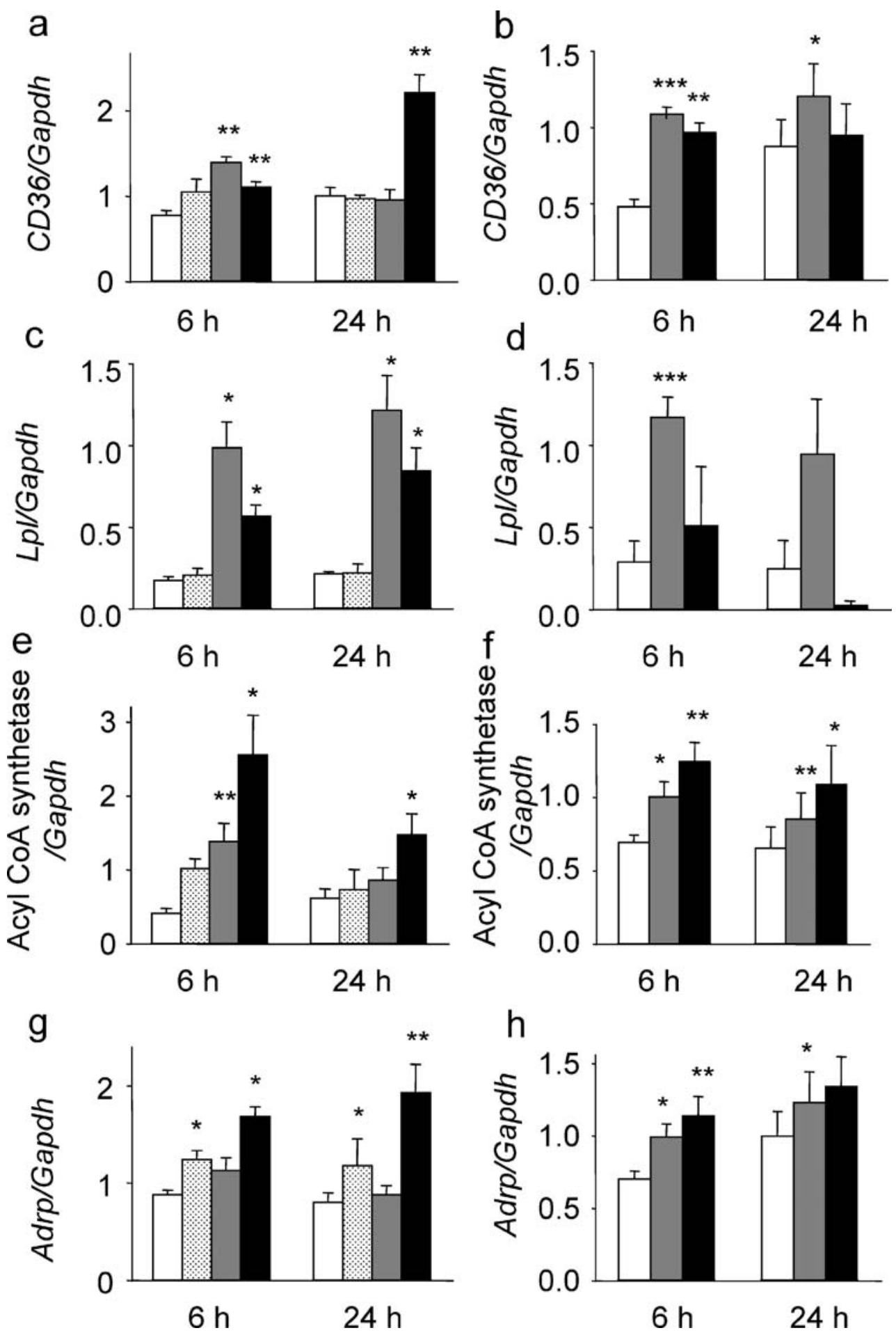

GW501516, previously shown to activate PPAR- $\delta$ highly selectively but not the other PPAR isoforms [11], was therefore selected for further experiments. Similar results were obtained in INS-1E cells (data not shown). No effect was observed when the parental thymidine kinase luciferase plasmid lacking the PPRE was used (Fig. 3), or with the PPAR- $\alpha$ agonist gemfibrozil (300 $\mu \mathrm{mol} / \mathrm{l}$, data not shown), confirming the specificity of the results.
PPAR- $\delta$ activation does not affect insulin secretion by beta cells

Glucose-induced and/or NEFA-induced insulin release from islets was measured following a 24-h exposure to $1 \mu \mathrm{mol} / 1$ GW501516. Insulin release to the medium by GW501516treated islets was not different from that by control islets over the 24 -h culture period ( $93 \pm 13 \%$ of control). Glucose 

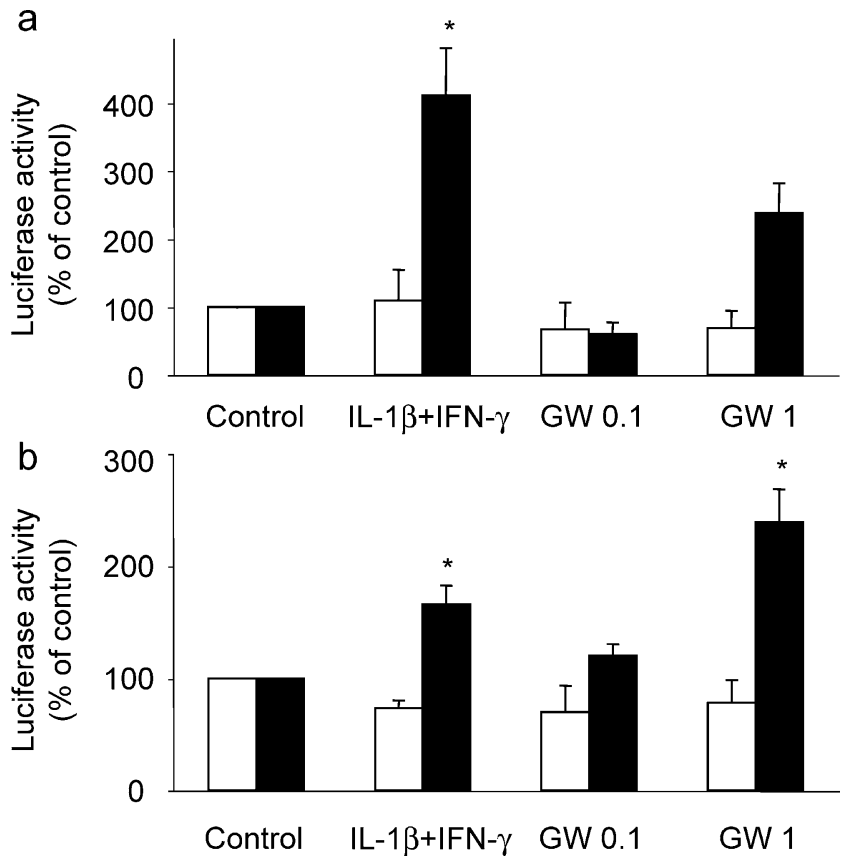

Fig. 3 Cytokines and GW501516 activate the PPAR- $\delta$ nuclear receptor in beta cells. Primary beta cells were co-transfected with the PPRE-containing acyl CoA oxidase luciferase reporter construct and the internal control pRL-CMV encoding Renilla luciferase (black bars). As negative controls, cells were transfected with the parental thymidine kinase luciferase plasmid lacking the PPRE (empty bars). After transfection, the cells were exposed for $12 \mathrm{~h} \mathrm{(a)} \mathrm{and} 24 \mathrm{~h}$ (b) to IL-1 $\beta$ + IFN- $\gamma$ or GW501516 (GW 0.1-1 $\mu$ mol/1) and assayed for firefly and Renilla luciferase activities. The results were normalised for Renilla luciferase activity and are means \pm SE of four or five independent experiments. ${ }^{*} p<0.05$ vs control

(16.7 $\mathrm{mmol} / \mathrm{l})$ or glucose $(16.7 \mathrm{mmol} / \mathrm{l})$ plus palmitate $(0.5 \mathrm{mmol} / \mathrm{l})$ induced a four- to sevenfold increase in insulin release as compared to $1.7 \mathrm{mmol} / \mathrm{l}$ glucose, and this was not modified by GW501516 (Table 1). GW501516 also failed to affect insulin release at $5.6 \mathrm{mmol} / 1$ glucose (Table 1). Insulin release at $1.7 \mathrm{mmol} / 1$ glucose was similar in control and GW501516-treated islets (data not shown).

PPAR- $\delta$ activation does not prevent Mcp-1 expression or NF- $\mathrm{KB}$ activation in beta cells

IL- $1 \beta+$ IFN- $\gamma$ treatment led to a clear induction of $M c p-1$ mRNA levels in INS-1E cells (Fig. 4). The PPAR- $\delta$ agonist GW501516 did not affect $M c p-1$ expression per se and did not prevent the cytokine effects (Fig. 4). Similarly, basal Mcp- 1 promoter activity and activation of the reporter construct by TNF- $\alpha$, IL- $1 \beta$ or IL- $1 \beta+$ IFN- $\gamma$ were not modified by GW501516 (data not shown).

In INS-1E cells transfected with an NF-kB reporter construct, GW501516 did not affect basal luciferase activity or the tenfold cytokine-induced increase in luciferase activity (data not shown). In line with these observations, GW501516 did not inhibit the cytokine-mediated mRNA

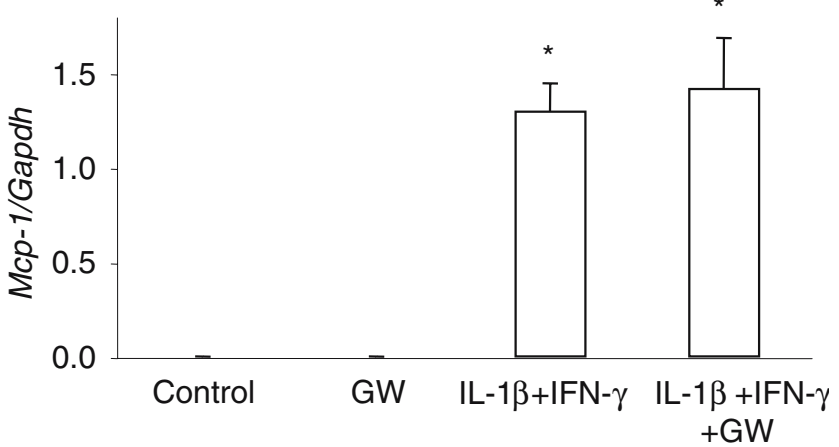

Fig. 4 PPAR- $\delta$ activation does not modify cytokine-induced MCP-1 expression in beta cells. Mcp-1 mRNA expression was analysed by real-time PCR and normalised for the expression of the housekeeping gene Gapdh. INS-1E cells were cultured for $10 \mathrm{~h}$ in the presence or absence of GW501516 ( $1 \mu \mathrm{mol} / \mathrm{l})$ before IL- $1 \beta+\mathrm{IFN}-\gamma$ exposure in the continuous presence of GW501516 or control condition for $6 \mathrm{~h}$ $(n=3) .{ }^{*} p<0.05$ vs control

induction of the NF-kB-regulated genes $i N O S$ and $I \kappa B-\alpha$ (data not shown). We also evaluated the effect of PPAR- $\delta$ activation on cytokine-induced primary beta cell apoptosis. The combination of IL- $1 \beta$ and IFN- $\gamma$ induced apoptosis in $19 \pm 2 \%$ of the beta cells after $48 \mathrm{~h}$, and this was not affected by GW501516 $(21 \pm 3 \%$ apoptosis, $n=3)$. Apoptosis in control beta cells was $3 \pm 1 \%(n=3)$, and this was not

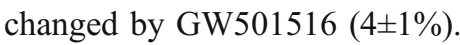

Pancreatic beta cells do not express the transcriptional repressor BCL-6, but transient BCL-6 expression inhibits the pro-inflammatory response in beta cells

PPAR- $\delta$ inhibits MCP-1 expression in macrophages by virtue of its ligand-dependent dissociation from the transcriptional repressor BCL-6 [16]. Because GW501516 did not decrease $M c p-1$ induction (Fig. 4), we examined whether pancreatic islets, FACS-purified primary beta cells or INS-1E cells express BCL-6. Bcl-6 was not detected in any of these cells, whereas a clear expression was observed in splenic tissue, used as positive control (Fig. 5).

To test whether the lack of constitutive BCL-6 expression could explain the defective beta cell response to the PPAR- $\delta$ agonist, we transiently transfected INS-1E cells

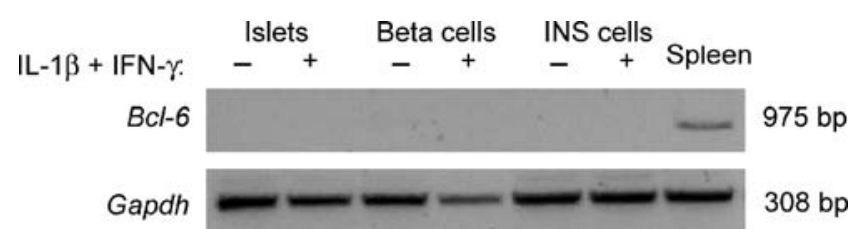

Fig. 5 Beta cells do not express the transcriptional repressor BCL-6. Rat islets, FACS-purified primary beta cells and INS-1E cells were cultured in the presence or absence of IL- $1 \beta+\mathrm{IFN}-\gamma$ for $24 \mathrm{~h}$. Bcl-6 expression was assessed by PCR and Gapdh was used as a housekeeping gene. Rat spleen was used as a positive control. One representative experiment for three similar experiments is shown 
with a BCL-6 expression plasmid or an empty control vector, both containing a haemagglutinin tag. After 24 to $48 \mathrm{~h}$, haemagglutinin immunocytochemistry confirmed nuclear staining in the cells transfected with the BCL-6 construct (data not shown). Following co-transfection with the $M c p-1$ promoter reporter (Fig. 6a), BCL-6 reduced basal and cytokine-induced $M c p-1$ promoter activity. This inhibitory effect appeared to be mediated through inhibition of NF- $\mathrm{kB}$, because BCL-6 effectively prevented cytokinemediated NF- $K B$ activation in a co-transfection experiment with the NF-kB reporter (Fig. 6b). Basal NF- $\kappa B$ activity was decreased to $40 \%$ of control, and cytokine-induced activation to $25 \%$.

\section{Discussion}

In previous microarray studies of INS-1E cells exposed to IL- $1 \beta+$ IFN- $\gamma$, we observed the induction of a large set of genes involved in lipid metabolism, among them the transcription factor Ppar- $\delta$ and several of its target genes
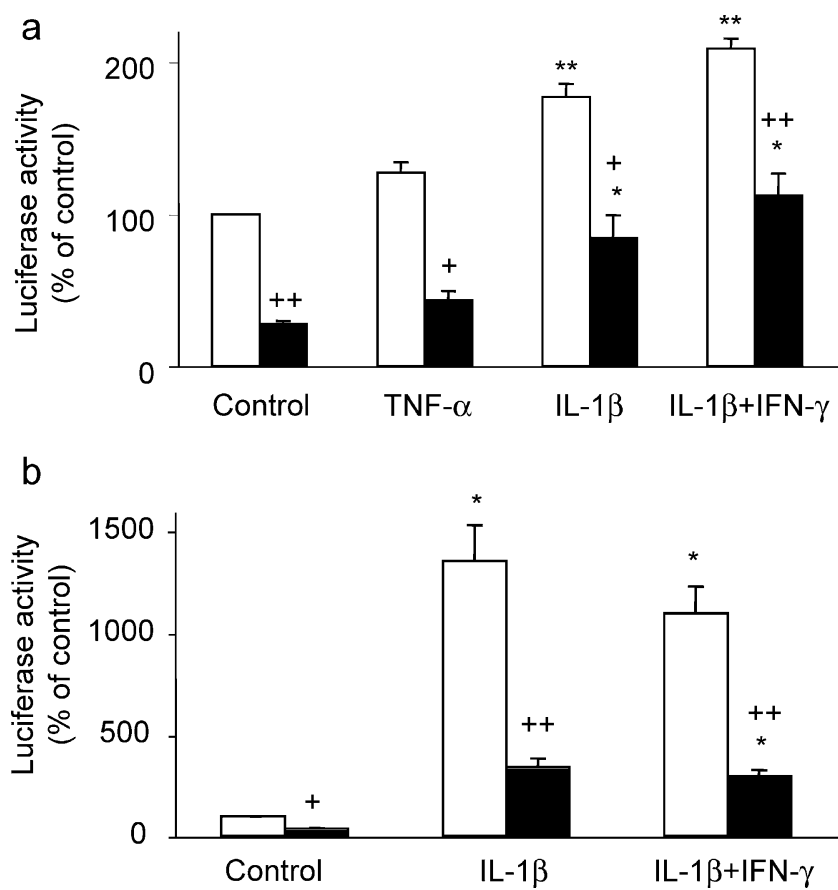

Fig. 6 BCL-6 decreases cytokine-induced MCP-1 promoter and NF$\mathrm{KB}$ activity in beta cells. a MCP-1 activation was examined using the Mcp-1 promoter luciferase reporter construct transfected in parallel with the BCL-6 expression construct (black bars) or the empty control vector (empty bars) in INS-1E cells exposed to cytokines for $14 \mathrm{~h}$. The results were normalised for Renilla luciferase activity and are means \pm SE of five independent experiments. b NF- $\kappa B$ activation was examined using a luciferase reporter construct transfected in parallel to the BCL-6 expression construct (black bars) or the empty control vector (white bars) in INS-1E cells exposed to cytokines for $6 \mathrm{~h}$. The results were normalised for Renilla luciferase activity and are means \pm SE of four independent experiments. ${ }^{*} p<0.05,{ }^{*} p<0.01$ vs control; $+p<0.05,++p<0.01$ vs empty vector
[7]. In the present study, we confirm by real-time PCR that the PPAR- $\delta$ gene network is induced by cytokines in INS-1E cells, and we extend these findings to primary rat beta cells. The upregulation of Ppar- $\delta$ mRNA is functional, as suggested by the PPRE reporter activation by cytokines and the induction of the PPAR- $\delta$ target genes $C D 36, \mathrm{Lpl}$, acyl CoA synthetase and Adrp. Because PPAR- $\delta$ was recently shown to control an inflammatory switch via its interaction with the transcriptional repressor BCL-6 [16], we examined whether PPAR- $\delta$ induction and activation regulates the cytokine-mediated pro-inflammatory response in pancreatic beta cells. At variance with immune cells, the synthetic PPAR- $\delta$ agonist GW501516 did not affect the expression and promoter activity of the chemokine MCP-1, probably because the transcriptional repressor BCL-6 is not expressed in beta cells. Neither did PPAR- $\delta$ activation inhibit cytokine-mediated NF- $\mathrm{kB}$ activation, nor did it protect beta cells against apoptotic cell death. BCL-6 expression by transient transfection inhibited the beta cell pro-inflammatory responses.

Of the three isoforms of the PPAR family, PPAR- $\alpha,-\gamma$ and $-\delta$, PPAR $-\delta$ is the predominant form in pancreatic islets [17]. Its expression levels increase when beta cells are exposed to cytokines, while no change was observed in PPAR- $\alpha$ or $-\gamma$ expression [7]. The role of PPAR- $\delta$ in beta cells is unknown, but PPAR- $\alpha$ is induced and promotes NEFA oxidation in beta cells at low glucose levels, i.e. during fasting and starvation, and decreases glucosestimulated insulin secretion [29], while PPAR- $\gamma$ overexpression in islets also impairs glucose-stimulated insulin secretion $[30,31]$. On the other hand, and at variance with the mention of increased islet insulin release in another report [14], PPAR- $\delta$ activation by its synthetic ligand GW501516 did not affect glucose- and NEFA-stimulated insulin secretion (present data).

In immune cells, PPAR- $\delta$ controls the inflammatory responses through its association (pro-inflammatory) and disassociation (anti-inflammatory) with the transcriptional repressor BCL-6 [16]. As in the case of MCP-1, BCL-6 can act directly or indirectly (via binding to other factors such as IRF and STAT) to repress chemokine expression [32]. We have previously demonstrated the importance of two NF- $\mathrm{kB}$ binding sites in the enhancer region of the Mcp-1 promoter, while the proximal promoter region with putative $\mathrm{NF}-\mathrm{kB}$ or AP-1 sites, a $\gamma$-activated sequence and an IFN response-inhibitory sequence contributed little to the regulation of MCP-1 expression in pancreatic beta cells [25]. BCL-6 can also negatively regulate NF-KB [33] by repressing its transcription and inhibiting its nuclear binding activity. Independent of BCL-6, PPARs may also exert anti-inflammatory effects via cross-talk with NF-kB. Recent data suggest that NF- $\mathrm{KB}$ activation may lead to PPAR $-\delta$ inhibition in cardiomyocytes, through physical 
interaction between the p 65 subunit of NF- $\mathrm{KB}$ and PPAR- $\delta$ [34]. Conversely, synthetic ligand-mediated PPAR- $\delta$ activation can inhibit NF- $\mathrm{kB}$ activation [35]. These regulatory mechanisms vary between tissues, as illustrated by the differences in PPAR- $\delta$-mediated repression of MCP-1 expression in liver and aorta [36].

In pancreatic beta cells, cytokines activate both NF-kB and PPAR- $\delta$, but PPAR $-\delta$ agonists did not decrease basal or cytokine-stimulated NF- $\mathrm{KB}$ activity, suggesting limited cross-talk between both pathways. Perhaps more importantly, and in contrast to immune cells, we found that beta cells do not express the transcriptional repressor BCL-6, and we demonstrated that transient BCL- 6 expression inhibits these pro-inflammatory responses. The lack of BCL- 6 expression, and PPAR- $\delta$-mediated repression of inflammatory responses, may render the beta cell particularly prone to propagation of inflammation through uninhibited NF-KB activation and MCP-1 expression. Stable transfection of beta cells with BCL-6 in vitro may restrict their chemokine release in the acute inflammatory reaction following islet transplantation and in the case of recurrent autoimmune disease and could be a means to prevent the development and amplification of insulitis.

In conclusion, PPAR- $\delta$ activation does not regulate the pro-inflammatory and pro-apoptotic response of beta cells to cytokines during insulitis in type 1 diabetes because beta cells lack BCL-6. Additional experiments, using in vivo models of prolonged PPAR- $\delta$ activation and BCL- 6 expression, are required to clarify the role of PPAR- $\delta$ and BCL-6 in beta cell physiology and to establish their therapeutic potential in type 1 diabetes.

Acknowledgements This work was supported by a grant from the European Foundation for the Study of Diabetes-Novo Nordisk Programme in Diabetes Research, by the European Union (Integrated Project EuroDia LSHM-CT-2006-518153 in the Framework Programme 6 [FP6] of the European Community), by grants from the Fondation David \& Alice Van Buuren (ULB), the Fonds National de la Recherche Scientifique (FNRS), Fonds de la Recherche Scientifique Médicale (FRSM) and Actions de Recherche Concertées da la Communauté Française, Belgium (to M. Cnop and D. L. Eizirik). We thank D. Silberbergh for performing the reporter assays with PPAR- $\alpha$ agonists, B. Kutlu and A. K. Cardozo for discussions and helpful suggestions during the study, L. Ladriere for help with the viability assays, J. Rasschaert for FACS sorting of primary beta cells, and G. Vandenbroeck and N. El Amrite for expert technical assistance.

\section{References}

1. Eizirik DL, Mandrup-Poulsen T (2001) A choice of death-the signal-transduction of immune-mediated $\beta$-cell apoptosis. Diabetologia 44:2115-2133

2. Cnop M, Welsh N, Jonas JC, Jörns A, Lenzen S, Eizirik DL (2005) Mechanisms of pancreatic $\beta$-cell death in type 1 and type 2 diabetes: many differences, few similarities. Diabetes 54 (Suppl 2):S97-S107
3. Cardozo AK, Heimberg H, Heremans Y et al (2001) A comprehensive analysis of cytokine-induced and nuclear factor$\mathrm{kB}$-dependent genes in primary rat pancreatic $\beta$-cells. J Biol Chem 276:48879-48886

4. Eldor R, Yeffet A, Baum K et al (2006) Conditional and specific NF- $\mathrm{BB}$ blockade protects pancreatic beta cells from diabetogenic agents. Proc Natl Acad Sci USA 103:5072-5077

5. Heimberg H, Heremans Y, Jobin $C$ et al (2001) Inhibition of cytokine-induced NF- $\mathrm{kB}$ activation by adenovirus-mediated expression of a NF- $\mathrm{KB}$ super-repressor prevents $\beta$-cell apoptosis. Diabetes 50:2219-2224

6. Cardozo AK, Proost P, Gysemans C, Chen MC, Mathieu C, Eizirik DL (2003) IL- $1 \beta$ and IFN- $\gamma$ induce the expression of diverse chemokines and IL-15 in human and rat pancreatic islet cells, and in islets from pre-diabetic NOD mice. Diabetologia 46:255-266

7. Kutlu B, Cardozo AK, Darville MI et al (2003) Discovery of gene networks regulating cytokine-induced dysfunction and apoptosis in insulin-producing INS-1 cells. Diabetes 52:2701-2719

8. Ricote M, Li AC, Willson TM, Kelly CJ, Glass CK (1998) The peroxisome proliferator-activated receptor- $\gamma$ is a negative regulator of macrophage activation. Nature 391:79-82

9. Peters JM, Lee SS, Li W et al (2000) Growth, adipose, brain, and skin alterations resulting from targeted disruption of the mouse peroxisome proliferator-activated receptor $\beta(\delta)$. Mol Cell Biol 20:5119-5128

10. Vosper H, Patel L, Graham TL et al (2001) The peroxisome proliferator-activated receptor $\delta$ promotes lipid accumulation in human macrophages. J Biol Chem 276:44258-44265

11. Oliver WR Jr, Shenk JL, Snaith MR et al (2001) A selective peroxisome proliferator-activated receptor $\delta$ agonist promotes reverse cholesterol transport. Proc Natl Acad Sci USA 98:5306-5311

12. Cheng L, Ding G, Qin Q et al (2004) Cardiomyocyte-restricted peroxisome proliferator-activated receptor- $\delta$ deletion perturbs myocardial fatty acid oxidation and leads to cardiomyopathy. Nat Med 10:1245-1250

13. Dressel U, Allen TL, Pippal JB, Rohde PR, Lau P, Muscat GE (2003) The peroxisome proliferator-activated receptor $\beta / \delta$ agonist, GW501516, regulates the expression of genes involved in lipid catabolism and energy uncoupling in skeletal muscle cells. Mol Endocrinol 17:2477-2493

14. Tanaka T, Yamamoto J, Iwasaki S et al (2003) Activation of peroxisome proliferator-activated receptor $\delta$ induces fatty acid $\beta$-oxidation in skeletal muscle and attenuates metabolic syndrome. Proc Natl Acad Sci USA 100:15924-15929

15. Lee $\mathrm{CH}$, Olson P, Hevener A et al (2006) PPAR $\delta$ regulates glucose metabolism and insulin sensitivity. Proc Natl Acad Sci USA 103:3444-3449

16. Lee CH, Chawla A, Urbiztondo N, Liao D, Boisvert WA, Evans RM (2003) Transcriptional repression of atherogenic inflammation: modulation by PPAR $\delta$. Science 302:453-457

17. Braissant O, Foufelle F, Scotto C, Dauca M, Wahli W (1996) Differential expression of peroxisome proliferator-activated receptors (PPARs): tissue distribution of PPAR- $\alpha,-\beta$, and $-\gamma$ in the adult rat. Endocrinology 137:354-366

18. Rasschaert J, Ladriere L, Urbain M et al (2005) Toll-like receptor 3 and STAT- 1 contribute to double-stranded RNA + interferon- $\gamma$ induced apoptosis in primary pancreatic $\beta$-cells. J Biol Chem 280:33984-33991

19. Asfari M, Janjic D, Meda P, Li G, Halban PA, Wollheim CB (1992) Establishment of 2-mercaptoethanol-dependent differentiated insulin-secreting cell lines. Endocrinology 130:167-178

20. Chen MC, Proost P, Gysemans C, Mathieu C, Eizirik DL (2001) Monocyte chemoattractant protein-1 is expressed in pancreatic islets from prediabetic NOD mice and in interleukin-1 $\beta$-exposed human and rat islet cells. Diabetologia 44:325-332 
21. Kharroubi I, Rasschaert J, Eizirik DL, Cnop M (2003) Expression of adiponectin receptors in pancreatic $\beta$ cells. Biochem Biophys Res Commun 312:1118-1122

22. Overbergh L, Valckx D, Waer M, Mathieu C (1999) Quantification of murine cytokine mRNAs using real time quantitative reverse transcriptase PCR. Cytokine 11:305-312

23. Chen MC, Schuit F, Eizirik DL (1999) Identification of IL-1 $\beta$ induced messenger RNAs in rat pancreatic beta cells by differential display of messenger RNA. Diabetologia 42:1199-1203

24. Chawla A, Lee CH, Barak Y et al (2003) PPAR $\delta$ is a very lowdensity lipoprotein sensor in macrophages. Proc Natl Acad Sci USA 100:1268-1273

25. Kutlu B, Darville MI, Cardozo AK, Eizirik DL (2003) Molecular regulation of monocyte chemoattractant protein-1 expression in pancreatic $\beta$-cells. Diabetes 52:348-355

26. Darville MI, Eizirik DL (1998) Regulation by cytokines of the inducible nitric oxide synthase promoter in insulin-producing cells. Diabetologia 41:1101-1108

27. Eizirik DL (1991) Interleukin- $1 \beta$ induces an early decrease in insulin release, (pro)insulin biosynthesis and insulin mRNA in mouse pancreatic islets by a mechanism dependent on gene transcription and protein synthesis. Autoimmunity 10:107-113

28. Hoorens A, Van de Casteele M, Kloppel G, Pipeleers D (1996) Glucose promotes survival of rat pancreatic $\beta$ cells by activating synthesis of proteins which suppress a constitutive apoptotic program. J Clin Invest 98:1568-1574

29. Gremlich S, Nolan C, Roduit R et al (2005) Pancreatic islet adaptation to fasting is dependent on peroxisome proliferator- activated receptor $\alpha$ transcriptional up-regulation of fatty acid oxidation. Endocrinology 146:375-382

30. Ito E, Ozawa S, Takahashi K et al (2004) PPAR- $\gamma$ overexpression selectively suppresses insulin secretory capacity in isolated pancreatic islets through induction of UCP-2 protein. Biochem Biophys Res Commun 324:810-814

31. Parton LE, Diraison F, Neill SE et al (2004) Impact of PPAR $\gamma$ overexpression and activation on pancreatic islet gene expression profile analyzed with oligonucleotide microarrays. Am J Physiol Endocrinol Metab 287:E390-E404

32. Dent AL, Vasanwala FH, Toney LM (2002) Regulation of gene expression by the proto-oncogene BCL-6. Crit Rev Oncol Hematol 41:1-9

33. Li Z, Wang X, Yu RY et al (2005) BCL-6 negatively regulates expression of the NF-kB1 p105/p50 subunit. J Immunol 174:205214

34. Planavila A, Laguna JC, Vazquez-Carrera M (2005) Nuclear factor$\mathrm{KB}$ activation leads to down-regulation of fatty acid oxidation during cardiac hypertrophy. J Biol Chem 280:17464-17471

35. Berry EB, Keelan JA, Helliwell RJ, Gilmour RS, Mitchell MD (2005) Nanomolar and micromolar effects of 15-deoxy- $\delta 12$, 14-prostaglandin $\mathrm{J} 2$ on amnion-derived WISH epithelial cells: differential roles of peroxisome proliferator-activated receptors $\gamma$ and $\delta$ and nuclear factor $\mathrm{kB}$. Mol Pharmacol 68:169-178

36. Tous M, Ferre N, Rull A et al (2006) Dietary cholesterol and differential monocyte chemoattractant protein-1 gene expression in aorta and liver of apo E-deficient mice. Biochem Biophys Res Commun 340:1078-1084 